\title{
A MEMORIAL TO WILLIAM HARVEY.
}

\author{
REBUILDING THE TOWER OF HEMPSTEAD CHURCH.
}

Sosre years ago a committee was formed to carry out the rebuilding of the tower of Hempstead Church as a Hatvey memorial, and some $£ 1,000$ was raised, in part locally and in part from the medical profession. Recently the committee has been reconstituted, and an appeal in the following terms is about to be issued to the medical profcssion:

The mortal remaiins of William Harrey, the great sxponent of the experimental method in biology and the founder of scientific medicine, lie in a sarcophagus in Hempstead Church, Essex, to which they were transferred in the fear 1883 from the Harey vault beneath the church at the cost of the Roral College of Physicians of London. Hempstead Church, a fourteenth century church of rery considerable interest, was closely linked with the Harvers, and contains sereral memorials to other nembers of this family who achieved distinction in nany branches of human activity.

This elsurh must alwars make a very special appeal to all conrected with the profession of medicine, since it is the place of burial of one who renclered not only in his own time, but for all time, the greatest service to medicine, by cstablishing it on a necure foundation, and also by inculcating the method by which its progress and development could best be furthered.

On January 28th, 1882, the tower of this ancient church collapsed, and the heap of ruins remains in the churchyard to this lay, imparting to the surroundings an air of desolation that must be seen to be appreciated.

Upwards of $£ 1,000$ has been collected towards the $£ 5,700$ required to meet the estimated cost of rebuilding the tower with the old materials. This appeal is addressed to the medical profession of the British Empire, in the hope that the sum required to restore the tower may be obtained with as little delay as possible, and so enable a suitable memorial to be raised to the memory of Harvey by those best qualified to appreciate the greatmess of his achicrement and the service he rendered to humanity.

The chairman of the Harrey Memorial Committee is Sir John Rose Bradford, President of the Royal College of Physicians of London; the vice-chairman is Lord Stammore, treasurer of St. Bartholomew's Hospital; and among its niembers are the Regius Professors of Medicine at Oxford and Cambridge, the Master of Caius, and the Warden of Merton, Sir Thomas Ballow, Sir Charles Sherrington, Sir D'Arcy Power, Sir William Hale-White, and Dr. Herbert Spencer. Donations should be made payable to the Harvey Memorial Fund, and may be sent to the honorary treasurer, Mr. A. W. Rugg!es-Brise (Spains Hall, Braintree), or to Dr. Arnold Stott (58, Harley Strect, W.1), who is acting es joint honorary secretary with the Vicar of Hempstead.

A detailed account of the Harvey Chapel, on the north side of the chancel, was written by Sir Dawson Williams, the late Editor of this Journal, shortly before his death, and appeared in our issue of May 12th, 1928 (p. 816).

Our first illustration, from an old woodcut, shows the church and its massive tower before 1882 ; the other two iliustrations show the "towcrless nave," from the west and south, as it stands to-day.

\section{HARVEY'S RUINED BURIAL PLACE.}

BY

Michael Grabham, M.D., ILL.D., Fellow of the Royal College of Physicians.

Hempstead lies in a sparsely peopled district of Essex, seven miles fiom any important town, and equally remote from railway communication. The parish church, a really fine structure showing pure Early English work, is probably 500 years old, and is built of hard chalky stone on one of those gravels which in the country are regarded as unstable and shifting if the stratum has the slightest tilt. Hence, or from some such cause, the massive tower of Hempstead Church, with its clock and fine peal of bells, collapsed fortyseven year's ago, broken from its very foundation, though the body of the church has not greatly suffered.

Now the interest of this church concerns all of us, and is twofold. Our first consideration is both medical and wolld-wide, for the body of William Harvey, who discovered the meaning of cardiac movements and the circulation of the blood and thus redirected the current of medical thought, is enshrined here in our custodianship for the hwman race; while secondly, the mortal remains of the celebrated Admiral Sir Eliab Harvey, in the kindred of our medical genius and one of Nelson's Trafalgar captains, are here preserved in the huge vault of the Harvey family. It is difficult to estimate the services of this intrepid cfficer in the crisis of the Trafalgar victory, for with one side of his vessel torn asunder he managed to get his remaining intact broadside to bear upon a fresh enemy ship "black with boarders," with annihilating effect. With perfect restraint and discipline he thus appears, by one single discharge, to have added a first-rate prize to the long list of Trafalgar captures. In early life, sixty-five years ago, I gathered much of the exploit I have related from conversation with Lady Bouchier and Admiral Codrington, children of one of Nelson's Trafalgar captains.

These two, then-our own William Harvey and Captain Harvey of Trafalgar-are our special concern, and the concer'n of the Empire, in the preservation of this Essex church. I have no shadow of authority to speak for the College of Physicians where responsibility for Hempstead has been assumed; but as senior Fellow-save one-I am confident of the indulgence of my colleagues when I venture to suggest that the co-operation of the British Medical Association is essential for the success of this rebuilding 
project. We are all members of this great Association; our influence is penetrating and all-pervading; everyone

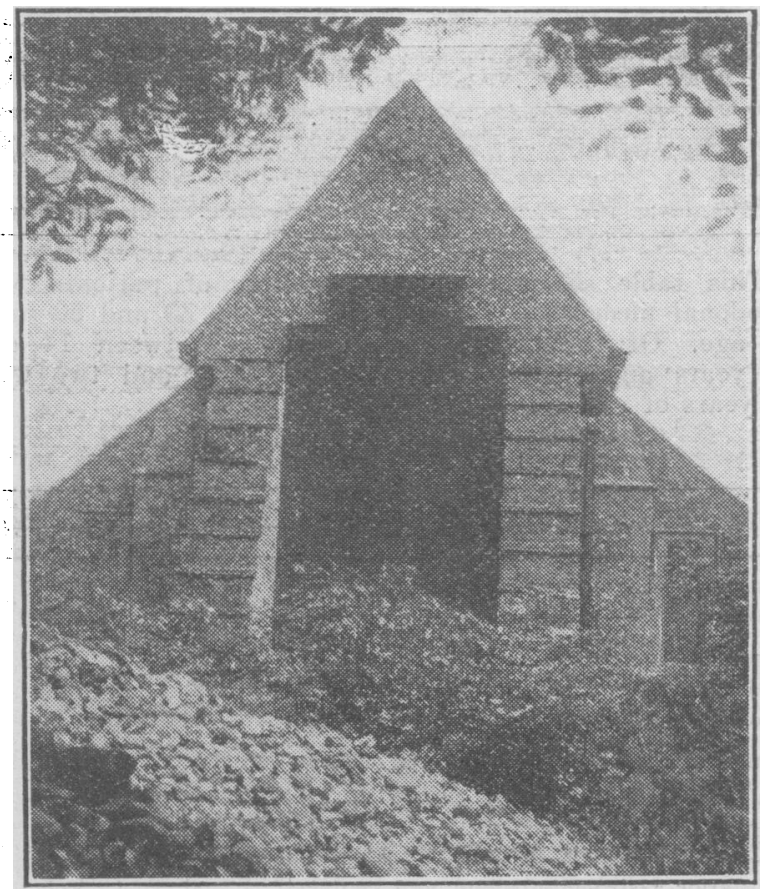

Hempstead Cinurch. West End after Collapse of Tower.

(From a photograph by Mr. F. D. Ilunt, Walthamstow.)

in the Empire is a patient of one of us and easily accessible, and it should be a privilege to all to help us. It should be quite easy, with our perfect organization, to make provision for the rebuilding of a church tower which touches us so vitally. Let us, with all haste and reverence, efface a

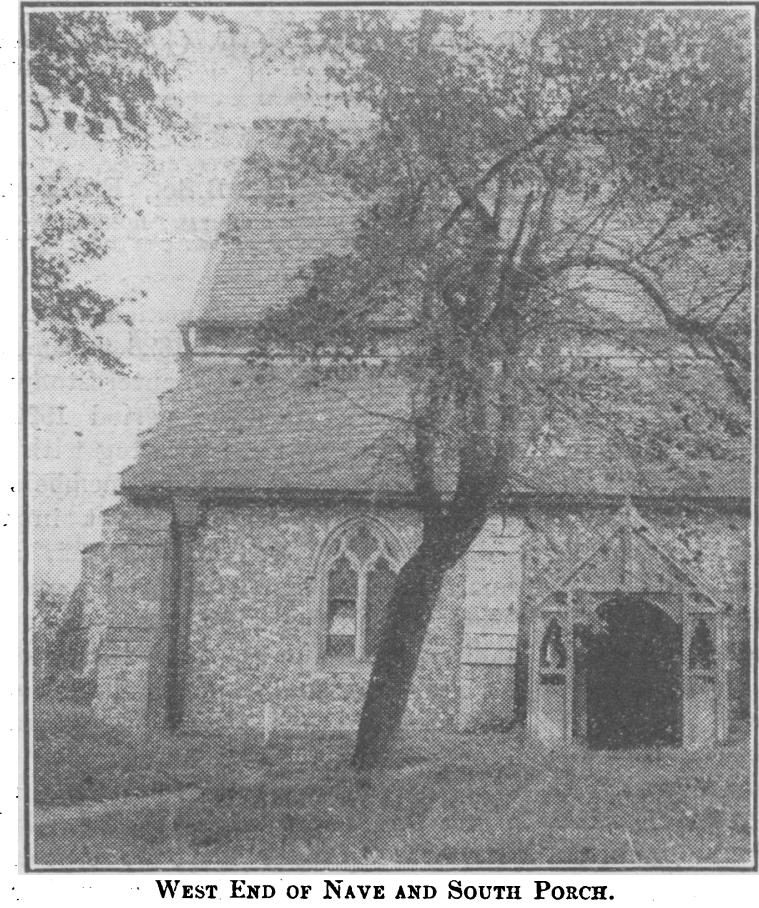

(From a photograph by Mr. George Walter Grabham, O.B.E., M.A.)

reproach obvious both medically and nationally in the ruins of this Essex church. The Trafalgar signal is still flying--England expects every man to do his duty.

\section{LONDON SCHOOL OF HYGIENE AND TROPICAL MEDICINE.}

Mefing of the Court of Governors.

THE first meeting of the Court of Governor's of the Iondon School of Hygiene and Tropical Medicine to be held in its new home at Bloomsbury took place on November 27th, with Sir Holbert Waring in the chair. It will be remembered that the building was opened by the Prince of Wales in July last.

Dr. Andrew Batforr, the director, gave an account of the work of the school during a year of great activity. As to the building, he said that some work still remained to be done; in particular, the large-scale biochemistry plant, the constant temperature room, the central photographic section, and that partion of the museum devoted to sanitary engineering and public health propaganda would not be wholly completed until a somewhat later date. With regard to the teaching, a scheme of study in public health, framed on different lines from any course hitherto in vogue, came into operation in October. Its chief feature was an attempt to co-ordinate the difierent branches of study in such a way that one dovetailed into another, and the whole formed a combined and logical exposition of the subject. Dr. Balfour illustrated by means of an elaborately coloured chart how the course was organized. Arrangements had been made for students to receive instruction in public health administration in the metropolitan borough of St. Marylebone and the urban district of Willesden, while the health departments of the London County Council, the City of London, and the Port of London had indicated their readiness to co-operate in the teaching work of the school. The medical officers of health for St. Marylebone and Willesden (Dr. Charles Porter and Dr. G. F. Buchan) were serving as lecturers on public health administration and practice, and a panel of visiting lecturers, experts in various branches of public health work, had been nominated for a peried of one year to assist the director of the division (Professor Jameson) in D.P.H. teaching. Certain alterations had also been made in the general course in tropical medicine and hygiene, the new course occupying twenty instead of seventeen weeks' instruction. In discussing the detailed work in the divisions and departments,
Ur. Balfour mentioned that Professor Jameson had paid a most fruitful visit to the United States, studying methods of public health teaching and practice in the principal schools of hygiene and some of the health departments of North America. He also spoke of the work overseas of the three officers holding appointments as lecturers or Milner Fellows in the departments of entomology, helminthology, and protozoology; of the success of the advanced courses in bacteriology and in epidemiology and vital statistics; of the developments in the library and museum; and of the progress made with research work, in which one group of subjects is financed mainly from the capital and interest of the Milner Research Fund, and the otherunder the Institute of Agricultural Parasitology - from Exchequer grants received through the Ministry of Agriculture.

Sir Holburt Waring, as treasurer, reported that at the end of the academic year there was a slight excess of income over expenditure. With regard to the capital account, on the site, building, and equipment there had been spent, up to the end of the financial year, approximately $£ 400,000$, and there rcmained a little over $£ 100,000$ still to pay. With regard to the future, the University Grants Committee had intimated that the Treasury had sanctioned a recurrent grant in aid at the rate of $\$ 40,000$ a year, but had impressed upon the school the necessity for taking all possible steps to secure an increased private income from the Colonies, from private or public subscriptions, and in other ways. General satisfaction had been cxpressed with regard to the new building, and especially with the lecture hall.

Sir. W. Arthur Robinson proposed a vote of thanks to Sir Holburt Waring and Dr. Balfour for their reports. The governors all felt that the school had made an excellent start in its new home. Sir Harry Goschen seconded the vote.

The Chaipman stated that the new Court of Governors, the members of which are appointed by about twenty-six official departments, university authorities, and voluntary associations, would be substantially the same as the old, except that the governors appointed by the General Medical Council would drop out. In view of its peculiar position in relation to the medical schools, the General Medical Council, while it had assisted in the recent developments, felt it inexpedient to cointinue permanently to appoint governors. 